ARTICLE

DOI: $10.1038 / s 41467-018-03890-w$

\title{
Fossil black smoker yields oxygen isotopic composition of Neoproterozoic seawater
}

\author{
F. Hodel (10 1,2, M. Macouin', R.I.F. Trindade², A. Triantafyllou³, J. Ganne', V. Chavagnac', J. Berger', \\ M. Rospabé (1) ${ }^{1}$, C. Destrigneville ${ }^{1}$, J. Carlut ${ }^{4}$, N. Ennih ${ }^{5}$ \& P. Agrinier ${ }^{4}$
}

The evolution of the seawater oxygen isotopic composition $\left(\delta^{18} \mathrm{O}\right)$ through geological time remains controversial. Yet, the past $\delta^{18} \mathrm{O}_{\text {seawater }}$ is key to assess past seawater temperatures, providing insights into past climate change and life evolution. Here we provide a new and unprecedentedly precise $\delta^{18} \mathrm{O}$ value of $-1.33 \pm 0.98 \%$ for the Neoproterozoic bottom seawater supporting a constant oxygen isotope composition through time. We demonstrate that the Ait Ahmane ultramafic unit of the ca. $760 \mathrm{Ma}$ Bou Azzer ophiolite (Morocco) host a fossil black smoker-type hydrothermal system. In this system we analyzed an untapped archive for the ocean oxygen isotopic composition consisting in pure magnetite veins directly precipitated from a Neoproterozoic seawater-derived fluid. Our results suggest that, while $\delta^{18} \mathrm{O}_{\text {seawater }}$ and submarine hydrothermal processes were likely similar to present day, Neoproterozoic oceans were $15-30^{\circ} \mathrm{C}$ warmer on the eve of the Sturtian glaciation and the major life diversification that followed.

\footnotetext{
${ }^{1}$ Géosciences Environnement Toulouse (GET), Observatoire Midi Pyrénées, Université de Toulouse, CNRS, IRD, UPS, 31400 Toulouse, France.

${ }^{2}$ Departamento de Geofísica, Instituto de Astronomia, Geofísica e Ciências Atmosféricas, Universidade de São Paulo, 05508-090 São Paulo, Brazil.

${ }^{3}$ Laboratoire de Planétologie et Géodynamique, UMR-CNRS 6112, Université de Nantes, 44322 Nantes, France. ${ }^{4}$ Institut de Physique du Globe de Paris, Université Sorbonne Paris Cité, Université Paris Diderot, CNRS, UMR 7154, 75005 Paris, France. ${ }^{5}$ EGGPG, Département de Géologie, Faculté des Sciences, Université Chouaib Doukkali, 24000 El Jadida, Morocco. Correspondence and requests for materials should be addressed to

F.H. (email: florent.hodel@hotmail.fr)
} 
W ere ancient oceans warmer than present-day oceans? This is an old and still unsettled debate that relates directly to the evolution of $\delta^{18} \mathrm{O}_{\text {seawater }}$ through time $\mathrm{e}^{1-}$ 9 . On the basis of the early recognition that the older the carbonates, the more negative their $\delta^{18} \mathrm{O}$ values, some authors suggested that $\delta^{18} \mathrm{O}_{\text {seawater }}$ has markedly increased since the Precambrian $^{2,5}$. Jaffrés et al. ${ }^{2}$ modeled an evolution from -13.3 to $0 \%$ of the $\delta^{18} \mathrm{O}_{\text {seawater }}$ since $3.4 \mathrm{Ga}$; the $\delta^{18} \mathrm{O}_{\text {seawater }}$ for the Neoproterozoic being $-6.4 \%$. According to this hypothesis, seawater temperature would be rather constant through time with temperatures similar to present-day ones since $3.4 \mathrm{Ga}^{2}$. Conversely, theoretical considerations suggest that the $\delta^{18} \mathrm{O}$ of the oceans remained buffered to a value of $0 \pm 2 \%$ since the early Archean due to seawater interaction with the oceanic lithosphere ${ }^{4,9}$. Recently, this idea of a rather constant $\delta^{18} \mathrm{O}_{\text {seawater }}$ for almost all the Earth's history was supported by data from chert-hosted kerogen ${ }^{6}$ and serpentinite ${ }^{10}$, which provided

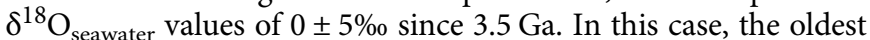
ocean would be much warmer, with temperatures $50-70{ }^{\circ} \mathrm{C}$ higher than today at $3.5 \mathrm{Ga}^{6,7}$. Until now, the test for these two hypotheses (increasing or constant $\delta^{18} \mathrm{O}_{\text {seawater }}$ over time) has hinged almost completely on the sedimentary isotope record. However, the sedimentary isotopic signal is known to be significantly affected by second-order processes such as evaporation, continental water percolation, and/or post-depositional interaction with pore water leading to important deviations from the true seawater value ${ }^{6}$. In the same way, the serpentinite isotopic composition may not reflect the seawater $\delta^{18} \mathrm{O}$ too, because the provided signal is partially controlled by the silicate minerals during the serpentinization process ${ }^{5,10}$. Therefore, a more accurate determination of the bottom seawater $\delta^{18} \mathrm{O}$ is still required to ultimately test the available hypotheses for $\delta^{18} \mathrm{O}_{\text {seawater }}$ evolution, and consequently the ocean's temperature evolution.
Here we investigate the serpentinites of the ca. $760 \mathrm{Ma}$ Bou Azzer ophiolite ${ }^{11-16}$ (Anti-Atlas, Morocco), hosting massive and well-preserved magnetite veins ${ }^{11,17,18}$. We confirm that these veins derived from a black smoker-type abyssal hydrothermalism $^{18}$. This high-quality isotopic archive consisting of pure magnetite from the massive veins allows us to propose an accurate $\delta^{18} \mathrm{O}$ value for the Neoproterozoic bottom seawater.

\section{Results}

Relics of a black smoker-type hydrothermalism. Serpentinites from the North Ait Ahmane unit of the Bou Azzer ophiolite ${ }^{11-15}$ (ca. $760 \mathrm{Ma}^{15,16}$, Morocco) experienced an intense hydrothermal activity that produced unusually massive, up to $5 \mathrm{~cm}$ thick magnetite veins ${ }^{11,17,18}$. A detailed magneto-petrographic study ${ }^{18}$ of the hydrothermalized serpentinites hosting the veins showed that an intense iron leaching in the serpentinites by a Cl-rich acidic fluid provided the iron for magnetite precipitation. Both abyssal and tardi-orogenic settings were proposed concerning the involved hydrothermal event ${ }^{18}$. Here we provide geochemical data on the serpentinites attesting that a black smoker-type (abyssal) hydrothermalism generated these unique magnetite veins.

Strong LREE and Eu enrichment are the hallmark of fluids exhaled by the present day black smoker-type abyssal hydrothermal vents ${ }^{19,20}$ (Figs. 1 and 2). In ultramafic rocks, such REE patterns are reported only for serpentinites originated from such abyssal hydrothermal vent fields ${ }^{21-24}$ (Figs. 1 and 2). Firstly, interpreted as the result of fluid/rock interaction with plagioclasebearing mafic rocks ${ }^{25-27}$, these LREE and Eu enrichments are now explained by the high mobility of these elements in acidic $\mathrm{Cl}$ rich fluids, due to chlorine complexation at low $\mathrm{pH}^{19,20}$. Chlorine complexation is also advanced to explain the ability of such acidic Cl-rich fluids to mobilize and transport significant amounts of

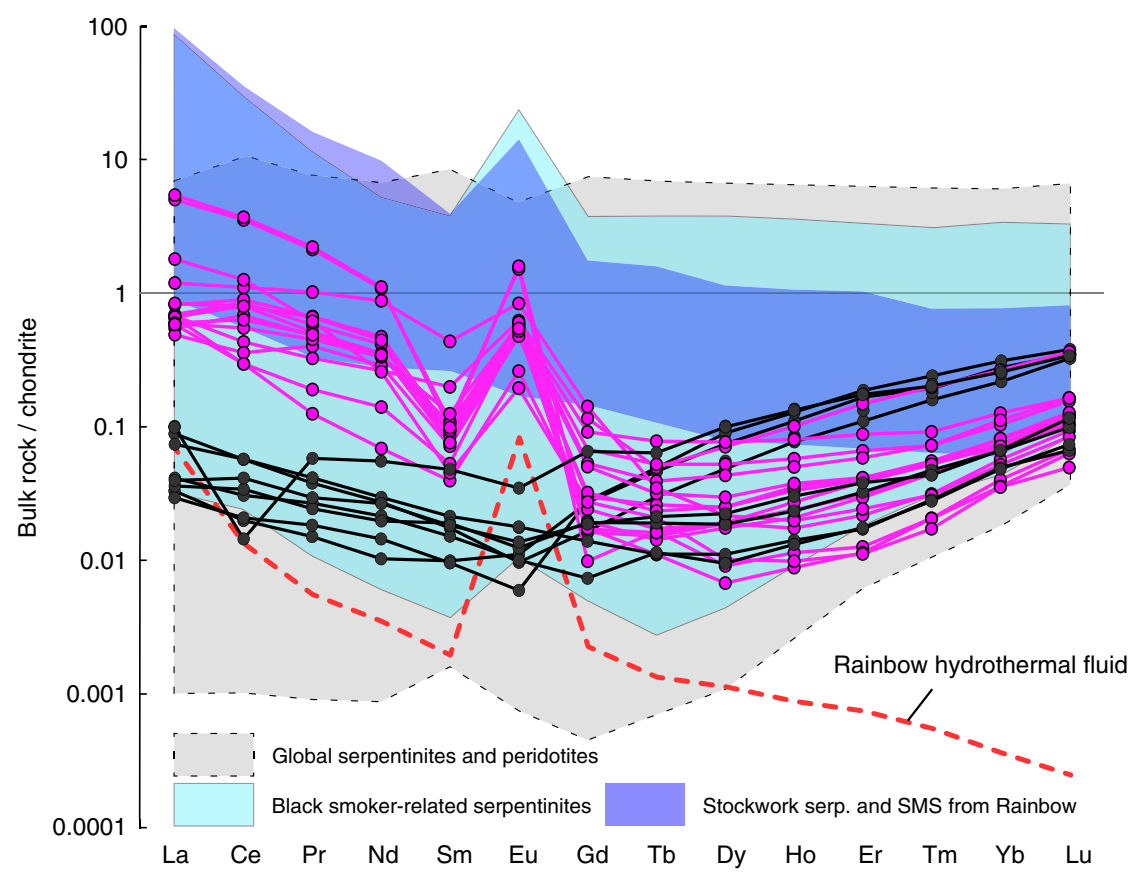

Fig. 1 Chondrite-normalized REE compositions of North Aït Ahmane serpentinites. Hydrothermalized serpentinites (in pink) exhibit significant LREE enrichment and positive Eu anomaly contrasting with unaffected serpentinites (in black). Black smoker fluid of Rainbow (red dotted line) displays the same LREE and Eu pattern despite its lower REE content ${ }^{19}$. Serpentinites and peridotites from abyssal ${ }^{21,28,61,62}$ and supra-subduction zone (SSZ) ${ }^{62-65}$ settings, black smoker-related serpentinites ${ }^{21-24}$, stockwork serpentinites and semi-massive sulphides from the Rainbow site ${ }^{23}$ are shown for comparison. Chondrite normalization values are from Barrat et al. ${ }^{66}$ 
100

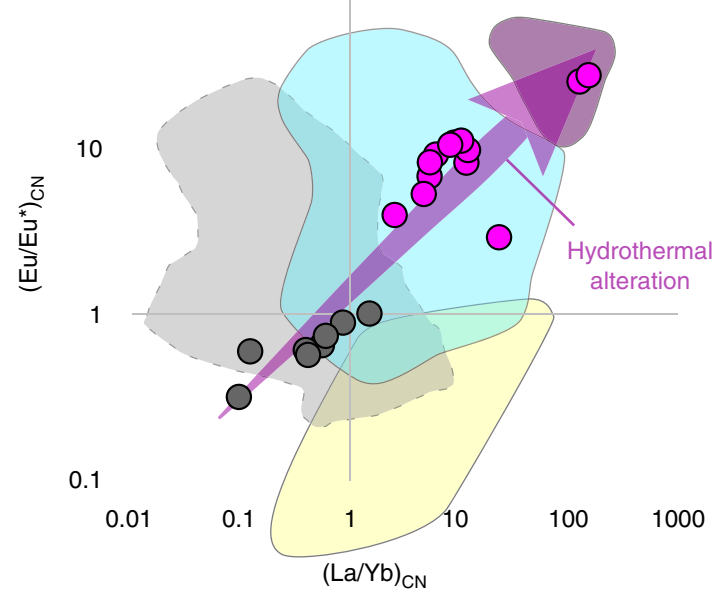

/O Hydrothermalized / unaffected serpentinites from North Aitt Ahmane

Global serpentinites and peridotites

Black smoker fluids

Black smoker-related serpentinites

Hercynian mineralizations

Fig. $2\left(\mathrm{Eu} / \mathrm{Eu}^{\star}\right)_{\mathrm{CN}}$ ratio vs. $(\mathrm{La} / \mathrm{Yb})_{\mathrm{CN}}$ ratio in North Aït Ahmane serpentinites. Data are compared with global serpentinites and peridotites $^{28,61,62,64,65}$ (in gray) and with black smoker-related serpentinites ${ }^{21-24}$ (in blue). Correlated enrichment in LREE and Eu in hydrothermalized serpentinites from Aït Ahmane tends toward those of black smoker fluids sampled at the sites of Rainbow ${ }^{19}$, Logatchev ${ }^{19}$, and Manus basin ${ }^{20}$ (in purple). Carbonates hosting tardi-orogenic

mineralizations in Bou Azzer inlier, dated at $310 \pm 5 \mathrm{Ma}^{30}$, plot in a clearly different field (in yellow), discarding a post-obduction process ${ }^{18}$ for Eu and LREE enrichments in the serpentinites. Chondrite normalization values are from Barrat et al. ${ }^{66}$

transition metals, including iron (forming $\mathrm{Fe}-\mathrm{Cl}$ complexes), within abyssal hydrothermal systems ${ }^{19}$. Here, we report identical geochemical features for the hydrothermalized serpentinites of the North Aït Ahmane unit (Fig. 1; see Supplementary Data 1). These serpentinites clearly display strong LREE enrichments ([La/ $\mathrm{Yb}]_{\mathrm{CN}}$ up to 152 ) correlated with positive Eu anomalies ([Eu/ $\left.\mathrm{Eu}^{*}\right]_{\mathrm{CN}}$ up to 27.4), contrasting with unaffected serpentinites displaying classical U-shaped REE patterns (Figs. 1 and 2). Further support for the hydrothermal origin of this chemical signature, in opposition to magmatic refertilization processes, is provided by the lack of correlation between HFSE and LREE enrichments in our samples, since HFSE are immiscible in lowtemperature aqueous solutions ${ }^{21,28,29}$ (Fig. 3a). By contrast, the geochemical signature of carbonates related to the tardi-orogenic event $^{30}$ significantly differs (Fig. 2), ruling out a post-obduction setting for serpentinites' alteration and magnetite veins' genesis.

In addition, high $\mathrm{As}$ and $\mathrm{Sb}$ concentrations also characterize serpentinites from current black smoker vent fields due to hydrothermal fluid/rock interactions ${ }^{23,24}$. The high As and $\mathrm{Sb}$ contents of the North Aï Ahmane serpentinites (As: 0.43-224 p.p. m., Sb: 0.01-0.73 p.p.m.) are akin to As and Sb contents in these modern black smoker hosted serpentinites ${ }^{23,24}$. A late sedimentary origin for these high As concentrations is very unlikely, given the absence of correlated LILE enrichments ${ }^{31}$.

Interestingly, accessory minerals are also affected in current black smoker systems, such as Cr-spinels, which are extensively altered and display important Mn-rich ferritchromite alteration rims (up to 4.53 wt.\% $\mathrm{MnO})^{32}$. As previously shown by Hodel et al. ${ }^{18}$, the hydrothermal alteration of the North Ait Ahmane serpentinites also drastically affected the Cr-spinels they host. Ferritchromite and $\mathrm{Cr}$-magnetite rims resulting from this
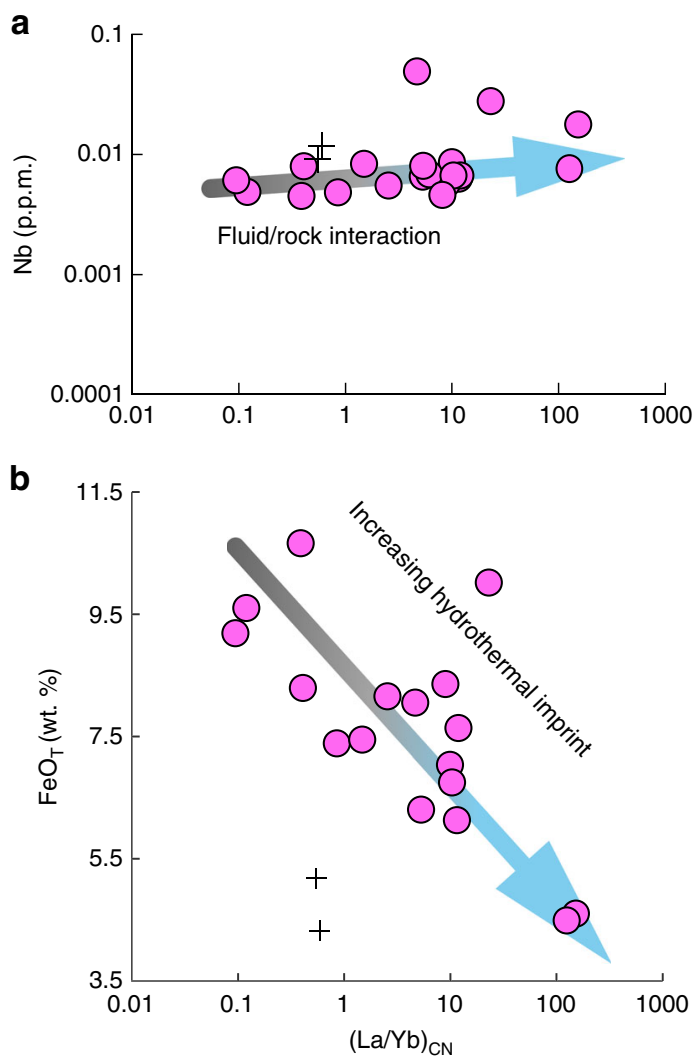

Fig. $3 \mathrm{Nb}$ and $\mathrm{FeO}_{\mathrm{T}}$ contents versus $(\mathrm{La} / \mathrm{Yb})_{\mathrm{CN}}$ ratio in North Ait Ahmane serpentinites. a Non-correlation between $(\mathrm{La} / \mathrm{Yb})_{\mathrm{CN}}$ ratio and $\mathrm{Nb}$ content attests to the hydrothermal origin of LREE enrichment. b Negative correlation between $\mathrm{FeO}_{\mathrm{T}}$ and $(\mathrm{La} / \mathrm{Yb})_{\mathrm{CN}}$ highlights the relationship between black smoker-type hydrothermalism and iron leaching in serpentinites involved in magnetite veins formation. Black crosses are antigorite veins. $\mathrm{La}$ and $\mathrm{Yb}$ are normalized to chondrite ${ }^{66}$

alteration are highly enriched in $\mathrm{Mn}$, up to 5.41 wt.\% of $\mathrm{MnO}^{18,33}$, which is once again exclusive to black smoker-related serpentinites $^{32}$. Finally, samples presenting the highest LREE enrichments and the strongest Eu anomalies are characterized by a high abundance of sulphides and can be analogous to the sulfide-rich serpentinites and stockworks of modern black smoker systems $^{23,24}$.

In sum, all these petrographical and geochemical features indicate that North Ait Ahmane serpentinites endured an abyssal black smoker-type hydrothermalism before the obduction of the ophiolitic sequence. Magnetite veins' formation from iron leaching by acidic Cl-rich fluid ${ }^{18}$ in these serpentinites clearly results from this abyssal hydrothermalism, as further evidenced by a negative correlation between total iron content and $(\mathrm{La} /$ $\mathrm{Yb})_{\mathrm{CN}}$ ratio (Fig. 3b). Thus, these massive magnetite veins and the associated hydrothermalized serpentinites likely represent the oldest fossil ultramafic-hosted black smoker-type hydrothermal system ever described.

Temperature of the involved fluid. The absence of antigorite in the studied hydrothermalized serpentinites constrains the temperature of the involved fluid to below $350{ }^{\circ} \mathrm{C}^{34,35}$. Clinochlore blades resulting from $\mathrm{Cr}$-spinel alteration during the abyssal hydrothermal event ${ }^{18}$ can be used to precisely infer its temperature using chlorite thermometry ${ }^{36-39}$. Here, we used the semi-empirical chlorite thermometer of Lanari et al. ${ }^{36}$, which is based on a recent thermodynamic model for di-trioctahedral chlorite from experimental and natural data in the system MgO- 


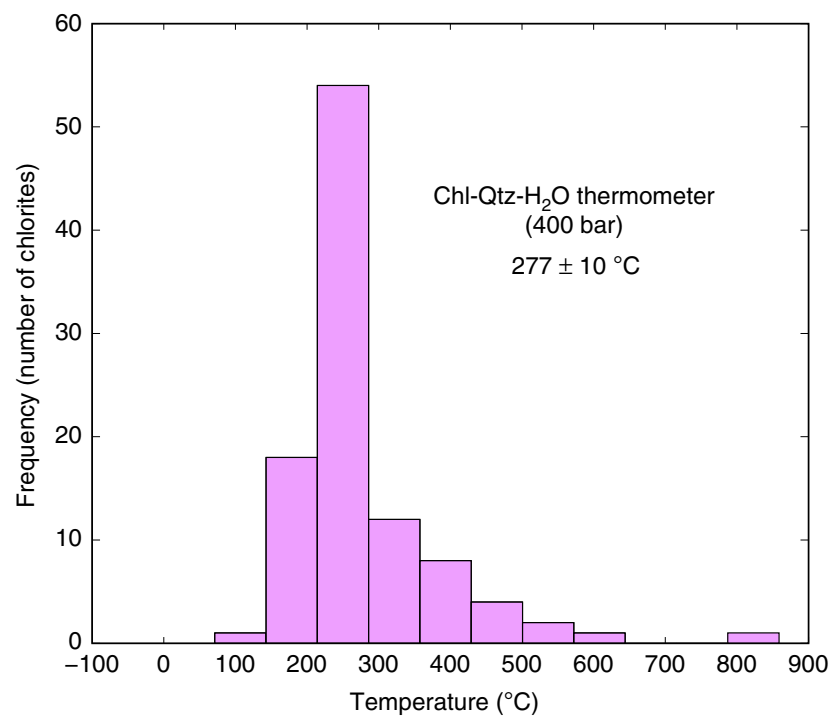

Fig. 4 Calculated temperature for the hydrothermal event. Bootstrap statistical analysis ${ }^{40}$ on chlorite temperatures calculated at 400 bar using the Chlorite-Qtz- $\mathrm{H}_{2} \mathrm{O}$ thermometer ${ }^{36}$

$\mathrm{FeO}-\mathrm{Al}_{2} \mathrm{O}_{3}-\mathrm{SiO}_{2}-\mathrm{H}_{2} \mathrm{O}^{36-38}$. Temperatures were calculated for a range of four different pressures (between $300 \mathrm{bar}$ and $2.5 \mathrm{kbar}$ ) using bootstrap statistical analysis to set aside badly crystallized chlorites $^{40}$ (Fig. 4; see Supplementary Data 2). Since black smoker-type hydrothermalism occurs at the seafloor subsurface, the most reasonable associated pressure must be 400 bar, which corresponds to a $3000 \mathrm{~m}$ water column and a $1 \mathrm{~km}$ fluid penetration depth within the oceanic lithosphere ${ }^{24}$. It is worth noting that chlorite crystallization due to Cr-Spinel hydrothermal alteration is closely linked with magnetite veins' precipitation, the involved hydrothermal fluid in both cases being likely the same ${ }^{18}$. Thus, the temperature of $277 \pm 10^{\circ} \mathrm{C}$ assessed by chlorite thermometry is also the temperature of the hydrothermal fluid during magnetite veins' precipitation and can be used to constrain the oxygen isotopes fractionation between hydrothermal fluid and magnetite.

$\delta^{18} \mathrm{O}$ of Neoproterozoic seawater. In the North Ait Ahmane black smoker system, iron was leached out from the host serpentinites by the hydrothermal fluid and transported as $\mathrm{Fe}-\mathrm{Cl}$ complexes up to the cracks, where it precipitated in the form of iron oxide ${ }^{18-20,41-43}$. Hence, the large amount of oxygen required to precipitate magnetite $\left(\mathrm{Fe}_{3} \mathrm{O}_{4}\right)$ as massive veins directly stems from the seawater-derived hydrothermal fluid circulating in the system. Consequently, the magnetite isotopic oxygen composition is necessarily in equilibrium with this hydrothermal fluid. Therefore, massive pure magnetite veins formed during this abyssal hydrothermalism are ideal targets to assess the $\delta^{18} \mathrm{O}$ of Neoproterozoic seawater. We measured the oxygen isotopic composition of pure magnetite $\left(\delta^{18} \mathrm{O}_{\mathrm{Mgt}}\right)$ from five magnetite veins. $\delta^{18} \mathrm{O}_{\mathrm{Mgt}}$ values range from -9.33 to $-8.16 \%$ with a mean value of $-8.95 \pm 0.42 \%$ (Fig. 5 ; see Supplementary Table 1). The mean $\delta^{18} \mathrm{O}$ for the fluid $\left(\delta^{18} \mathrm{O}_{\text {fluid }}\right)$ in equilibrium with the magnetite of these veins was calculated at $-0.42 \pm 0.55 \%$ using a Mgt- $\mathrm{H}_{2} \mathrm{O}$ fractionation $\mathrm{law}^{44}$ and the temperature set at $277 \pm 10$ ${ }^{\circ} \mathrm{C}$ (Fig. 5; see Methods, Supplementary Table 1 and Supplementary Fig. 1). For comparison, a maximum temperature of 302 $\pm 11^{\circ} \mathrm{C}$ (at $2.5 \mathrm{kbar}$ ) and a minimum temperature of $273 \pm 10^{\circ} \mathrm{C}$ (at $300 \mathrm{bar}$ ) would provide similar $\delta^{18} \mathrm{O}_{\text {fluid }}$ values, respectively $-0.52 \pm 0.54 \%$ and $-0.41 \pm 0.56 \%$, attesting the robustness of our estimate.

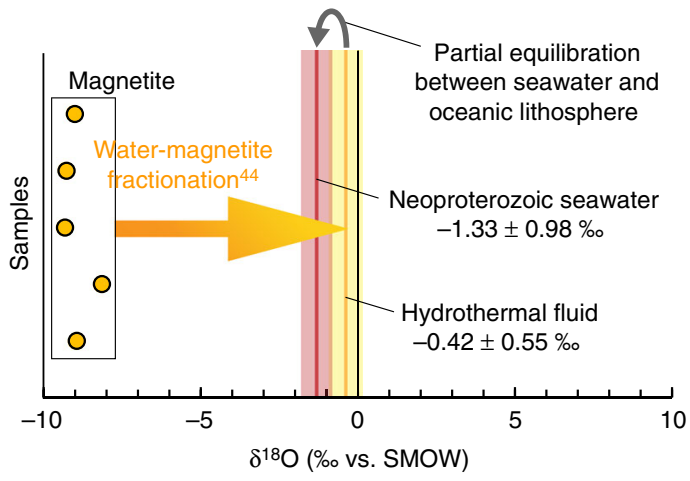

Fig. 5 Oxygen isotope compositions of the hydrothermal magnetite. Measured $\delta^{18} \mathrm{O}$ compositions of pure magnetite from five veins (orange dots), assessment of the isotopic composition of the involved hydrothermal fluid and calculation of the corresponding seawater isotopic composition

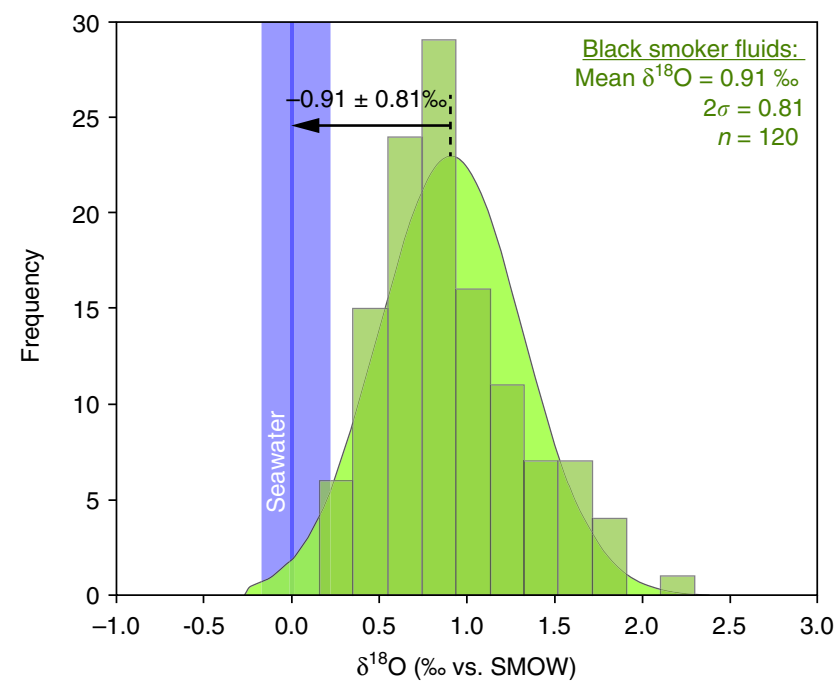

Fig. 6 Partial $\delta^{18} \mathrm{O}$ equilibration between present-day bottom seawater and black smoker fluids. Distribution histogram and associated curve (in green) for a compilation of black smoker fluids' $\delta^{18} O$ values $(n=120)^{45-48}$. Present-day bottom seawater range is represented in blue ${ }^{46,47}$

The value of $-0.42 \pm 0.55 \%$ we obtained for the hydrothermal fluid in equilibrium with the magnetite does not directly correspond to the $\delta^{18} \mathrm{O}$ of the Neoproterozoic bottom seawater. It has been shown that high-temperature abyssal hydrothermal fluids are enriched in ${ }^{18} \mathrm{O}$ relative to bottom seawater due to partial isotopic equilibration with mafic/ultramafic rocks of the oceanic lithosphere ${ }^{45}$. In order to quantify this partial equilibration, we compiled $\delta^{18} \mathrm{O}$ data from present-day black smoker fluids ${ }^{45-48}$ and associated bottom seawater values, respectively, $\delta^{18} \mathrm{O}_{\mathrm{BSfluid}}$ and $\delta^{18} \mathrm{O}_{\text {PDseawater }}$ (Fig. 6). $\delta^{18} \mathrm{O}_{\text {PDseawater values }}{ }^{46,47}$ are comprised between -0.17 and $0.22 \%$, while $\delta^{18} \mathrm{O}_{\text {Bsfluid }}$ values $(n=120)$ range from 0.16 to $2.30 \%$. These data attest to a high degree of overlap between $\delta^{18} \mathrm{O}_{\mathrm{PD} \text { seawater }}$ and $\delta^{18} \mathrm{O}_{\mathrm{BSfluid}}$ with a small difference between their mean values (Fig. 6). Because of the normal statistical distribution of $\delta^{18} \mathrm{O}_{\mathrm{BSfluid}}$ data (Fig. 6), the mean shift between $\delta^{18} \mathrm{O}_{\mathrm{BSfl}}$ uid and $\delta^{18} \mathrm{O}_{\mathrm{PDseawater}}$ can be used to quantify the fluid/rock equilibration. We obtained a $\Delta^{18} \mathrm{O}_{\text {BSfluid-PDseawater }}$ of $0.91 \pm 0.81 \%$ (Fig. 6 ).

Hence, a $\delta^{18} \mathrm{O}$ value for the Neoproterozoic bottom seawater can be estimated from our isotopic measurements on the North Ait Ahmane magnetite veins by subtracting this $\Delta^{18} \mathrm{O}_{\mathrm{BSfluid}}$ 


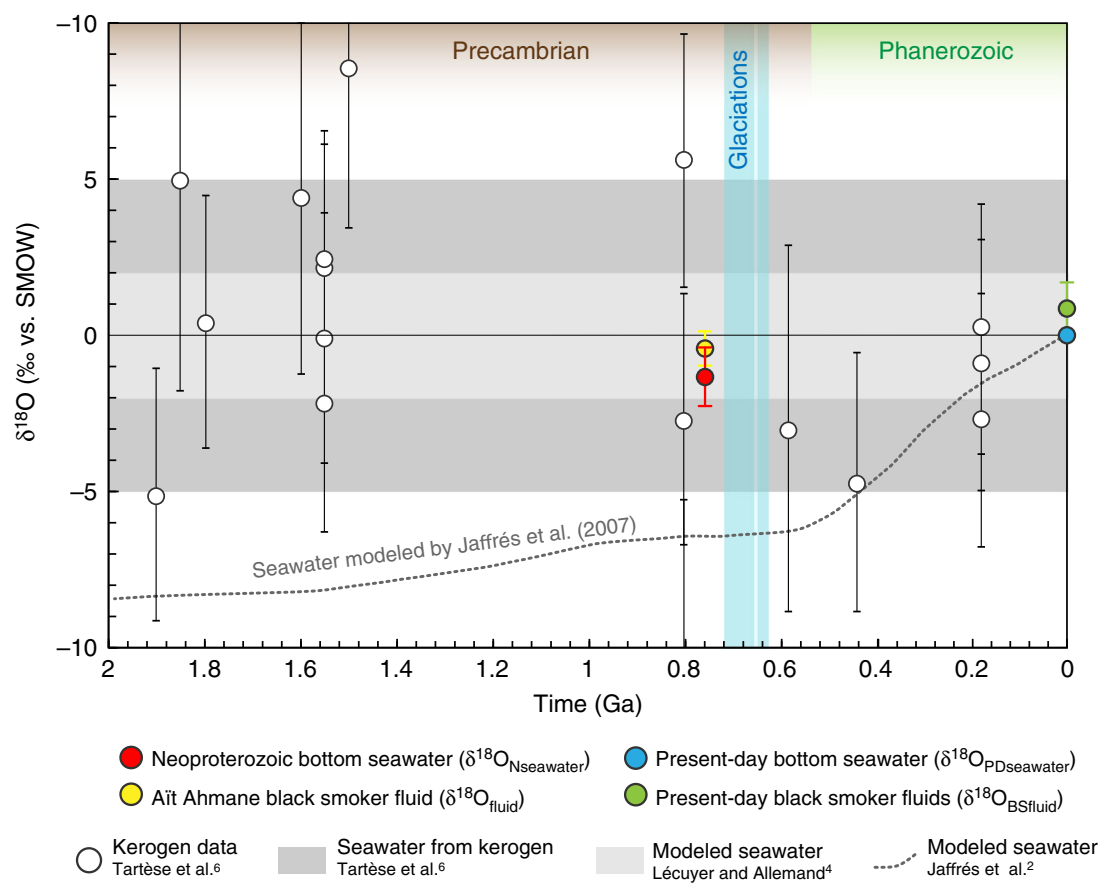

Fig. 7 Oxygen isotopic compositions of the Aït Ahmane hydrothermal fluid and estimate of Neoproterozoic bottom seawater $\delta^{18} \mathrm{O}$ compared with existing estimates along the past $2 \mathrm{Ga}$. Error bars for $\delta^{18} \mathrm{O}$ values of Ait Ahmane black smoker fluid and Neoproterozoic seawater were calculated following error propagation considering errors on mean $\delta^{18} \mathrm{O}$ value measured on magnetite, on temperature-dependent water-magnetite fractionation and on $\Delta^{18} \mathrm{O}_{\mathrm{BSfluid}}$ PDseawater ( $2 \sigma$ of the compiled data, Fig. 6 ), see Supplementary Table 1

PDseawater value to the $\delta^{18} \mathrm{O}_{\text {fluid }}$ calculated from magnetite veins (Fig. 5). In this manner, we obtained a $\delta^{18} \mathrm{O}_{\text {Nseawater value of }}$ $-1.33 \pm 0.98 \%$ o for the Neoproterozoic bottom seawater at 760 Ma (Figs. 5 and 7; see Supplementary Table 1).

\section{Discussion}

Global seawater $\delta^{18} \mathrm{O}$ is essentially controlled by seafloor hydrothermal alteration, meaning the interaction of seawater with oceanic lithosphere in hydrothermal systems ${ }^{2-4,8,9}$. The ratio between high and low-temperature alteration has been evoked as maintaining the seawater $\delta^{18} \mathrm{O}$ constant through time ${ }^{4,8,9}$, partial isotopic equilibration mentioned above (Figs. 5 and 6) acting as a buffer. Some authors, however, argued that this ratio evolved through time due to a two-step rise of high-temperature abyssal hydrothermalism related to geodynamic changes since the Archean $^{2}$. Long-term changes in sea level are also evoked as having interfered in the $\delta^{18} \mathrm{O}$ regulation by changing the continental surface exposed to weathering ${ }^{2}$. Changes in sea level also influence water pressure at the bottom of the sea, regulating the depth of fluids penetration in mid-ocean ridge hydrothermal systems and thus the extent of high-temperature alteration ${ }^{2,3}$. The Neoproterozoic $\delta^{18} \mathrm{O}_{\text {seawater }}$ of $-1.33 \pm 0.98 \%$ that we provide here is much more precise than previous estimates (Fig. 7). This $\delta^{18} \mathrm{O}_{\text {Nseawater }}$ value is significantly higher than that of $-6.4 \%$ predicted by models considering an increasing $\delta^{18} \mathrm{O}_{\text {seawater }}$ through time $\mathrm{e}^{2}$. It means that the isotopic oxygen compositions of the Neoproterozoic oceans (at $760 \mathrm{Ma}$ ) was similar to that of the recent oceans, which is between -1.5 and $+1.8 \%{ }^{49}$, and $-1.4 \%$ o for an ice-free planet ${ }^{50}$. This result attests to a rather constant $\delta^{18} \mathrm{O}_{\text {seawater }}$ through time, at least since the Neoproterozoic. Hence, the ratio of low- and high-temperature hydrothermal activity, ocean volume, ridge depth, and global geodynamics would have been similar than in the present day, meaning that a modern tectonic-ocean system already prevailed at $760 \mathrm{Ma}$.
Finally, the $\delta^{18} \mathrm{O}_{\text {seawater }}$ presented here can be used to better constrain the temperature of the oceans at $760 \mathrm{Ma}$ when combined with the available oxygen isotope record of authigenic carbonates and cherts. Past ocean temperatures can be estimated from the isotopic fractionation between seawater and marine sediments. These sedimentary records display a general trend of increasing $\delta^{18} \mathrm{O}$ values from the Archean to the present ${ }^{2,4,51-54}$. Considering a steady $\delta^{18} \mathrm{O}_{\text {seawater }}$ since the Archean, this $\delta^{18} \mathrm{O}$ increase of carbonates and cherts is generally interpreted as resulting from the progressive cooling of the ancient oceans (from $\sim 70$ to $50^{\circ} \mathrm{C}$ during the Archean) ${ }^{4,6}$. By evoking the implausibility of such high temperatures, some authors proposed that the isotopic signal of these sedimentary archives could have been modified by pervasive alteration processes such as diagenesis, post-depositional interaction with pore water or hydrothermal fluids on the seafloor ${ }^{10,55}$. Nonetheless, the fact that this trend is recorded in different mineralogies (carbonate, dolostone, chert, and phosphates) $)^{2,3,6,7}$ and in different isotope systems (e.g., $\left.\delta^{30} \mathrm{Si}^{7}, \delta^{18} \mathrm{O}^{2,6}\right)$ attests to the reliability of these isotopic records. Given this, our validation of a constant $\delta^{18} \mathrm{O}_{\text {seawater indicates that }}$ the oceans were likely $15-30{ }^{\circ} \mathrm{C}$ warmer than today $760 \mathrm{Myr}$ ago, on the eve of the events of life diversification that occurred at the end of the Neoproterozoic.

\section{Methods}

Chlorite thermometry. Major element compositions of clinochlore associated with hydrothermal alteration ${ }^{18}$ were determined with a Cameca SXFive electron microprobe at the Centre de Micro Caractérisation Raimond Castaing (Université Toulouse III Paul Sabatier, France). Operating conditions were as follows: accelerating voltage $15 \mathrm{kV}$ and beam current $10 \mathrm{nA}$. Analyzed surface is $\sim 2 \times 2 \mu \mathrm{m}^{2}$. The following standards were used: albite $(\mathrm{Na})$, periclase $(\mathrm{Mg})$, corundum $(\mathrm{Al})$, sanidine $(\mathrm{K})$, wollastonite $(\mathrm{Ca}, \mathrm{Si})$, pyrophanite $(\mathrm{Mn}, \mathrm{Ti})$, hematite $(\mathrm{Fe}), \mathrm{Cr}_{2} \mathrm{O}_{3}(\mathrm{Cr}), \mathrm{NiO}$ $(\mathrm{Ni})$, sphalerite $(\mathrm{Zn})$, tugtupite $(\mathrm{Cl})$, barite $(\mathrm{Ba})$, and topaze $(\mathrm{F})$. Detection limits are estimated to be $0.01 \mathrm{wt} . \%$ for each element. Temperatures were assessed using the semi-empirical geothermometer of Lanari et al. ${ }^{36}$ (see Supplementary Data 2). Temperatures were calculated for a range of four different pressures $(300,400 \mathrm{bar}$, $1,2.5 \mathrm{kbar}$ ) to test the quality of the thermometer and gives very similar 
results: $273 \pm 10^{\circ} \mathrm{C}$ at 300 bar, $277 \pm 10^{\circ} \mathrm{C}$ at 400 bar, $283 \pm 10^{\circ} \mathrm{C}$ at $1 \mathrm{kbar}$, and $302 \pm 11^{\circ} \mathrm{C}$ at $2.5 \mathrm{kbar}$.

$\delta^{\mathbf{1 8}} \mathbf{O}$ measurements and calculation. Oxygen in pure magnetite from five massive magnetite veins was extracted as $\mathrm{O}_{2}$ gas via reaction with bromine pentafluoride $\left(\mathrm{BrF}_{5}\right)$. Oxygen ratios were measured on a Thermo Fisher Scientific Delta Plus XP mass spectrometer at the Institut de Physique du Globe de Paris (Paris, France). All values of $\delta^{18} \mathrm{O}\left[=\left[\left({ }^{18} \mathrm{O} /{ }^{16} \mathrm{O}\right)_{\text {sample }} /\left({ }^{18} \mathrm{O} /{ }^{16} \mathrm{O}\right)_{\text {standard }}-1\right] \times 1000\right]$ are normalized to VSMOW. NBS 28 reference material was measured at $9.48 \pm 0.10 \%$ o $(\sigma, n=7)$ during the course of this study. We tested two Mgt- $\mathrm{H}_{2} \mathrm{O}$ fractionation laws ${ }^{44,56}$ to assess the $\delta^{18} \mathrm{O}$ of the hydrothermal fluid involved in magnetite vein precipitation at $277 \pm 10^{\circ} \mathrm{C}$. In order to validate the predictions of these laws, we used the direct measurements of Fortier et $\mathrm{al}^{57}$ that provide a value of reference at $350^{\circ} \mathrm{C}$. Both laws predict a very similar $\mathrm{Mgt}-\mathrm{H}_{2} \mathrm{O}$ fractionation consistent with Fortier et al. ${ }^{57}$ measurements (see Supplementary Fig. 1). We retained the fractionation law proposed by Zheng and Simon ${ }^{44}$ because it is better suited for temperature estimated for magnetite veins precipitation $\left(277 \pm 10^{\circ} \mathrm{C}\right)$. Law by Cole et al. ${ }^{56}$ is limited to $300{ }^{\circ} \mathrm{C}$ and has large uncertainties below $500^{\circ} \mathrm{C}$.

Bulk-rock chemistry. Major element concentrations were obtained by alkaline fusion and ICP-OES analysis at the Service d'Analyse de Roches et des Minéraux (Nancy, France) following the analytical protocol of Carignan et $\mathrm{al}^{58}$. Whole-rock trace element concentrations were analyzed following the procedure of Ionov et al. ${ }^{59}$ adapted by for the analysis of ultra-depleted peridotites ${ }^{60}$ using an Agilent 7700x quadrupole ICP-MS at Géosciences Montpellier (Université Montpellier 2, France). Indium and Bismuth were used as internal standards during ICP-MS measurements. The precision and accuracy of ICP-MS analyses were assessed by measuring the reference materials BE-N (basalt) and UB-N (serpentinite).

Data availability. All data used in this manuscript are available in Supplementary Data 1, Supplementary Data 2, and Supplementary Table 1. Further queries and information requests should be directed to the lead author F.H. (florent.hodel@hotmail.fr).

Received: 27 September 2017 Accepted: 20 March 2018

Published online: 13 April 2018

\section{References}

1. Veizer, J., Godderis, Y. \& François, L. M. Evidence for decoupling of atmospheric $\mathrm{CO}_{2}$ and global climate during the Phanerozoic eon. Nature 408, 698-701 (2000).

2. Jaffrés, J. B. D., Shields, G. A. \& Wallmann, K. The oxygen isotope evolution of seawater: a critical review of a long-standing controversy and an improved geological water cycle model for the past 3.4 billion years. Earth Sci. Rev. 83, 83-122 (2007).

3. Kasting, J. F. \& Ono, S. Palaeoclimates: the first two billion years. Philos. Trans. R. Soc. Lond. B Biol. Sci. 361, 917-929 (2006).

4. Lécuyer, C. \& Allemand, P. Modelling of the oxygen isotope evolution of seawater: implications for the climate interpretation of the $\delta^{18} \mathrm{O}$ of marine sediments. Geochim. Cosmochim. Acta 63, 351-361 (1999).

5. Veizer, J. \& Prokoph, A. Temperatures and oxygen isotopic composition of Phanerozoic oceans. Earth Sci. Rev. 146, 92-104 (2015).

6. Tartèse, R., Chaussidon, M., Gurenko, A., Delarue, F. \& Robert, F. Warm Archaean oceans reconstructed from oxygen isotope composition of early-life remnants. Geochem. Perspect. Lett. 3, 55-65 (2017).

7. Robert, F. \& Chaussidon, M. A palaeotemperature curve for the Precambrian oceans based on silicon isotopes in cherts. Nature 443, 969-972 (2006).

8. Muehlenbachs, K. \& Clayton, R. N. Oxygen isotope composition of the oceanic crust and its bearing on seawater. J. Geophys. Res. 81, 4365-4369 (1976).

9. Gregory, R. T. \& Taylor, H. P. An oxygen isotope profile in a section of Cretaceous oceanic crust, Samail Ophiolite, Oman: evidence for $\delta^{18} \mathrm{O}$ buffering of the oceans by deep $(5 \mathrm{~km})$ seawater-hydrothermal circulation at mid-ocean ridges. J. Geophys. Res. Solid Earth 86, 2737-2755 (1981).

10. Pope, E. C., Bird, D. K. \& Rosing, M. T. Isotope composition and volume of Earth's early oceans. Proc. Natl Acad. Sci. USA 109, 4371-4376 (2012).

11. Leblanc, M. Ophiolites Précambriennes et Gites Arséniés De Cobalt (Bou Azzer - Maroc) (Université Paris VI, Paris, 1975).

12. Walsh, G. J. et al. Neoproterozoic tectonic evolution of the Jebel Saghro and Bou Azzer-El Graara inliers, eastern and central Anti-Atlas, Morocco. Precambrian Res. 216, 23-62 (2012).

13. Bodinier, J. L., Dupuy, C. \& Dostal, J. Geochemistry of Precambrian ophiolites from Bou Azzer, Morocco. Contrib. Mineral. Petrol. 87, 43-50 (1984).
14. Naidoo, D. D., Bloomer, S. H., Saquaque, A. \& Hefferan, K. Geochemistry and significance of metavolcanic rocks from the Bou Azzer-El Graara ophiolite (Morocco). Precambrian Res. 53, 79-97 (1991).

15. Hodel, F. Neoproterozoic Serpentinites: A Window on the Oceanic Lithosphere Associated With the Rodinia Break-Up (Université Toulouse III Paul Sabatier, 2017).

16. Triantafyllou, A. et al. Intra-oceanic arc growth driven by magmatic and tectonic processes recorded in the Neoproterozoic Bougmane arc complex (Anti-Atlas, Morocco). Precambrian Res. 304, 39-63 (2018).

17. Gahlan, H. A. et al. Origin of magnetite veins in serpentinite from the Late Proterozoic Bou-Azzer ophiolite, Anti-Atlas, Morocco: an implication for mobility of iron during serpentinization. J. African Earth Sci. 46, 318-330 (2006).

18. Hodel, F. et al. Unusual massive magnetite veins and highly altered Cr-spinels as relics of a Cl-rich acidic hydrothermal event in Neoproterozoic serpentinites (Bou Azzer ophiolite, Anti-Atlas, Morocco). Precambrian Res. 300, 151-167 (2017).

19. Douville, E. et al. The rainbow vent fluids ( $\left.36^{\circ} 14^{\prime} \mathrm{N}, \mathrm{MAR}\right)$ : the influence of ultramafic rocks and phase separation on trace metal content in Mid-Atlantic Ridge hydrothermal fluids. Chem. Geol. 184, 37-48 (2002).

20. Craddock, P. R. et al. Rare earth element abundances in hydrothermal fluids from the Manus Basin, Papua New Guinea: Indicators of sub-seafloor hydrothermal processes in back-arc basins. Geochim. Cosmochim. Acta 74, 5494-5513 (2010)

21. Paulick, H. et al. Geochemistry of abyssal peridotites (Mid-Atlantic Ridge, $15^{\circ}$ $20^{\prime} \mathrm{N}$, ODP Leg 209): Implications for fluid/rock interaction in slow spreading environments. Chem. Geol. 234, 179-210 (2006).

22. Augustin, N. et al. Alteration at the ultramafic-hosted Logatchev hydrothermal field: constraints from trace element and $\mathrm{Sr}-\mathrm{O}$ isotope data. Geochemistry, Geophys. Geosystems 13, Q0AE07 (2012).

23. Marques, A. F. A., Barriga, F., Chavagnac, V. \& Fouquet, Y. Mineralogy, geochemistry, and Nd isotope composition of the Rainbow hydrothermal field, Mid-Atlantic Ridge. Miner. Depos. 41, 52-67 (2006).

24. Andreani, M. et al. Tectonic structure, lithology, and hydrothermal signature of the Rainbow massif (Mid-Atlantic Ridge $36^{\circ} 14^{\prime} \mathrm{N}$ ). Geochem. Geophys. Geosystems 15, 3543-3571 (2014).

25. Klinkhammer, G., Elderfield, H., Edmond, J. \& Mitra, A. Geochemical implications of rare earth element patterns in hydrothermal fluids from midocean ridges. Geochim. Cosmochim. Acta 58, 5105-5113 (1994).

26. James, R. H., Elderfield, H. \& Palmer, M. R. The chemistry of hydrothermal fluids from the Broken Spur site, $29^{\circ} \mathrm{N}$ Mid-Atlantic ridge. Geochim. Cosmochim. Acta 59, 651-659 (1995).

27. Douville, E. et al. Yttrium and rare earth elements in fluids from various deepsea hydrothermal systems. Geochim. Cosmochim. Acta 63, 627-643 (1999).

28. Niu, Y. Bulk-rock major and trace element compositions of abyssal peridotites: implications for mantle melting, melt extraction and post-melting processes beneath mid-ocean ridges. J. Petrol. 45, 2423-2458 (2004).

29. You, C., Castillo, P., Gieskes, J. \& Chan, L. Trace element behavior in hydrothermal experiments: implications for fluid processes at shallow depths in subduction zones. Earth. Planet. Sci. Lett. 140, 41-52 (1996).

30. Oberthür, T. et al. Hercynian age of the colbalt-nickel-arsenide-(gold) ores, Bou Azzer, Anti-Atlas, Morocco: Re-Os, $\mathrm{Sn}-\mathrm{Nd}$, and U-Pb age determinations. Econ. Geol. 104, 1065-1079 (2009).

31. Debret, B. Serpentinites, Vecteurs des Circulations Fluides et des Transferts Chimiques de L'Océanisation à la Subduction: Exemple Dans les Alpes Occidentales (Université Blaise Pascal, Clermont-Ferrand II, 2013).

32. Marques, A. F. A., Barriga, F. J. A. S. \& Scott, S. D. Sulfide mineralization in an ultramafic-rock hosted seafloor hydrothermal system: From serpentinization to the formation of $\mathrm{Cu}-\mathrm{Zn}-(\mathrm{Co})$-rich massive sulfides. Mar. Geol. 245, 20-39 (2007).

33. Fanlo, I., Gervilla, F., Colás, V. \& Subías, I. Zn-, Mn- and Co-rich chromian spinels from the Bou-Azzer mining district (Morocco): constraints on their relationship with the mineralizing process. Ore Geol. Rev. 71, 82-98 (2015).

34. Schwartz, S. et al. Pressure-temperature estimates of the lizardite/antigorite transition in high pressure serpentinites. Lithos 178, 197-210 (2013).

35. Evans, B. W. The serpentinite multisystem revisited: chrysotile is metastable. Int. Geol. Rev. 46, 479-506 (2004).

36. Lanari, P., Wagner, T. \& Vidal, O. A thermodynamic model for ditrioctahedral chlorite from experimental and natural data in the system $\mathrm{MgO}-\mathrm{FeO}-\mathrm{Al}_{2} \mathrm{O}_{3}-\mathrm{SiO}_{2}-\mathrm{H}_{2} \mathrm{O}$ : applications to $\mathrm{P}-\mathrm{T}$ sections and geothermometry. Contrib. Mineral. Petrol. 167, 968 (2014).

37. Vidal, O., Parra, T. \& Trotet, F. A thermodynamic model for Fe-Mg aluminous chlorite using data from phase equilibrium experiments and natural pelitic assemblages in the 100 to $600^{\circ} \mathrm{C}, 1$ to $25 \mathrm{~kb}$ range. Am. J. Sci. 301, 557-592 (2001).

38. De Andrade, V., Vidal, O., Lewin, E., O'Brien, P. \& Agard, P. Quantification of electron microprobe compositional maps of rock thin sections: an optimized method and examples. J. Metamorph. Geol. 24, 655-668 (2006). 
39. Block, S. et al. Petrological and geochronological constraints on lower crust exhumation during Paleoproterozoic (Eburnean) orogeny, NW Ghana, West African Craton. J. Metamorph. Geol. 33, 463-494 (2015).

40. Ganne, J. et al. Statistical petrology reveals a link between supercontinents cycle and mantle global climate. Am. Mineral. 101, 2768-2773 (2016).

41. Purtov, V. K., Kholodnov, V. V., Anfilogov, V. N. \& Nechkin, G. S. The role of chlorine in the formation of magnetite skarns. Int. Geol. Rev. 31, 63-71 (1989).

42. Fein, J. B., Hemley, J. J., D’Angelo, W. M., Komninou, A. \& Sverjensky, D. A. Experimental study of iron-chloride complexing in hydrothermal fluids. Geochim. Cosmochim. Acta 56, 3179-3190 (1992).

43. Kalczynski, M. J. \& Gates, A. E. Hydrothermal alteration, mass transfer and magnetite mineralization in dextral shear zones, western Hudson Highlands, New York, United States. Ore Geol. Rev. 61, 226-247 (2014).

44. Zheng, Y.-F. \& Simon, K. Oxygen isotope fractionation in hematite and magnetite: a theoretical calculation and application to geothermometry of metamorphic iron-formations. Eur. J. Mineral. 3, 877-886 (1991).

45. Jean-Baptiste, P., Charlou, J. L. \& Stievenard, M. Oxygen isotope study of midocean ridge hydrothermal fluids: Implication for the oxygen-18 budget of the oceans. Geochim. Cosmochim. Acta 61, 2669-2677 (1997).

46. Bach, W. \& Humphris, S. E. Relationship between the $\mathrm{Sr}$ and $\mathrm{O}$ isotope compositions of hydrothermal fluids and the spreading and magma-supply rates at oceanic spreading centers. Geology 27, 1067 (1999).

47. Reeves, E. P. et al. Geochemistry of hydrothermal fluids from the PACMANUS, Northeast Pual and Vienna Woods hydrothermal fields, Manus Basin, Papua New Guinea. Geochim. Cosmochim. Acta 75, 1088-1123 (2011).

48. James, R. H. et al. Composition of hydrothermal fluids and mineralogy of associated chimney material on the East Scotia Ridge back-arc spreading centre. Geochim. Cosmochim. Acta 139, 47-71 (2014).

49. Carpenter, S. J. \& Lohmann, K. C. $\delta^{18} \mathrm{O}$ and $\delta^{13} \mathrm{C}$ values of modern brachiopod shells. Geochim. Cosmochim. Acta 59, 3749-3764 (1995).

50. Lhomme, N., Clarke, G. K. C. \& Ritz, C. Global budget of water isotopes inferred from polar ice sheets. Geophys. Res. Lett. 32, L20502 (2005).

51. Veizer, J. \& Hoefs, J. The nature of ${ }^{18} \mathrm{O} /{ }^{16} \mathrm{O}$ and ${ }^{13} \mathrm{C} /{ }^{12} \mathrm{C}$ secular trends in sedimentary carbonate rocks. Geochim. Cosmochim. Acta 40, 1387-1395 (1976).

52. Knauth, L. P. \& Lowe, D. R. Oxygen isotope geochemistry of cherts from the Onverwacht Group (3.4 billion years), Transvaal, South Africa, with implications for secular variations in the isotopic composition of cherts. Earth. Planet. Sci. Lett. 41, 209-222 (1978).

53. Wallmann, K. The geological water cycle and the evolution of marine $\delta^{18} \mathrm{O}$ values. Geochim. Cosmochim. Acta 65, 2469-2485 (2001).

54. Prokoph, A., Shields, G. A. \& Veizer, J. Compilation and time-series analysis of a marine carbonate $\delta^{18} \mathrm{O}, \delta^{13} \mathrm{C},{ }^{87} \mathrm{Sr} /{ }^{86} \mathrm{Sr}$ and $\delta^{34} \mathrm{~S}$ database through Earth history. Earth Sci. Rev. 87, 113-133 (2008).

55. Blake, R. E., Chang, S. J. \& Lepland, A. Phosphate oxygen isotopic evidence for a temperate and biologically active Archaean ocean. Nature 464, 1029-1032 (2010).

56. Cole, D. R. et al. An experimental and theoretical determination of oxygen isotope fractionation in the system magnetite- $\mathrm{H}_{2} \mathrm{O}$ from 300 to $800{ }^{\circ} \mathrm{C}$. Geochim. Cosmochim. Acta 68, 3569-3585 (2004).

57. Fortier, S. M. et al. Determination of the magnetite-water equilibrium oxygen isotope fractionation factor at $350^{\circ} \mathrm{C}$ : A comparison of ion microprobe and laser fluorination techniques. Geochim. Cosmochim. Acta 59, 3871-3875 (1995).

58. Carignan, J., Hild, P., Mevelle, G., Morel, J. \& Yeghicheyan, D. Routine analyses of trace elements in geological samples using flow injection and low pressure on-line liquid chromatography coupled to ICP-MS: a study of geochemical referencematerials BR, DR-N, UB-N, AN-G and GH. Geostand. Geoanal. Res. 25, 187-198 (2001).

59. Ionov, D. A., Savoyant, L. \& Dupuy, C. Application of the ICP-MS technique to trace element analysis of peridotites and their minerals. Geostand. Geoanal. Res. 16, 311-315 (1992).

60. Godard, M., Jousselin, D. \& Bodinier, J.-L. Relationships between geochemistry and structure beneath a palaeo-spreading centre: a study of the mantle section in the Oman ophiolite. Earth. Planet. Sci. Lett. 180, 133-148 (2000).
61. Godard, M., Lagabrielle, Y., Alard, O. \& Harvey, J. Geochemistry of the highly depleted peridotites drilled at ODP Sites 1272 and 1274 (Fifteen-Twenty Fracture Zone, Mid-Atlantic Ridge): implications for mantle dynamics beneath a slow spreading ridge. Earth Planet Sci. Lett. 267, 410-425 (2008).

62. Kodolányi, J., Pettke, T., Spandler, C., Kamber, B. S. \& Gméling, K. Geochemistry of ocean floor and fore-arc serpentinites: constraints on the ultramafic input to subduction zones. J. Petrol. 53, 235-270 (2012).

63. Parkinson, I. J. \& Pearce, J. A. Peridotites from the Izu-Bonin-Mariana Forearc (ODP Leg 125): evidence for mantle melting and melt-mantle interaction in a supra-subduction zone setting. J. Petrol. 39, 1577-1618 (1998).

64. Savov, I. P., Ryan, J. G., D'Antonio, M., Kelley, K. \& Mattie, P. Geochemistry of serpentinized peridotites from the Mariana Forearc Conical Seamount, ODP Leg 125: implications for the elemental recycling at subduction zones. Geochem. Geophys. Geosyst. 6, Q04J15 (2005).

65. Savov, I. P., Ryan, J. G., D’Antonio, M. \& Fryer, P. Shallow slab fluid release across and along the Mariana arc-basin system: Insights from geochemistry of serpentinized peridotites from the Mariana fore arc. J. Geophys. Res. 112, B09205 (2007).

66. Barrat, J. A. et al. Geochemistry of CI chondrites: major and trace elements, and $\mathrm{Cu}$ and $\mathrm{Zn}$ isotopes. Geochim. Cosmochim. Acta 83, 79-92 (2012).

\section{Acknowledgements}

We thank Olivier Bruguier, Chantal Douchet, and Léa Causse for their assistance on the ICP-MS. This work has been funded by TelluS-SYSTER program of INSU (CNRS), French MENESR, and Research Grant 2016/06114-6 of the São Paulo Research Foundation (FAPESP).

\section{Author contributions}

F.H., M.M., and R.I.F.T. conceived the study and wrote the paper with contribution from all co-authors. Field work and sampling were done by F.H., A.T., M.M., J.B., and N. E.; trace elements' chemistry was performed by F.H. and J.B. and interpreted by F.H., M. R., V.C., and J.C.; J.G. and F.H. did the thermometry study on chlorites. P.A. and F.H. performed the oxygen isotope measurements and C.D. did the statistics and error calculations.

\section{Additional information}

Supplementary information accompanies this paper at https://doi.org/10.1038/s41467 018-03890-w.

Competing interests: The authors declare no competing interests.

Reprints and permission information is available online at http://npg.nature.com/ reprintsandpermissions/

Publisher's note: Springer Nature remains neutral with regard to jurisdictional claims in published maps and institutional affiliations.

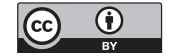

Open Access This article is licensed under a Creative Commons Attribution 4.0 International License, which permits use, sharing, adaptation, distribution and reproduction in any medium or format, as long as you give appropriate credit to the original author(s) and the source, provide a link to the Creative Commons license, and indicate if changes were made. The images or other third party material in this article are included in the article's Creative Commons license, unless indicated otherwise in a credit line to the material. If material is not included in the article's Creative Commons license and your intended use is not permitted by statutory regulation or exceeds the permitted use, you will need to obtain permission directly from the copyright holder. To view a copy of this license, visit http://creativecommons.org/ licenses/by/4.0/.

(C) The Author(s) 2018 